\title{
Against charity: Some preliminary considerations
}

\section{Bob Brecher}

\begin{abstract}
Charity is often viewed as a paradigm of morality. I suggest, however, that charitable action is morally problematic - even morally wrong. Following a brief characterisation of charity, it will be suggested that it wrongly puts recipients in a position of dependency and dispensers in a self-congratulatory position of political quietism.
\end{abstract}

Keywords: charity, dependency, gifts, needs

\section{Introduction}

In this brief, programmatic article I want to propose something that will probably appear counter-intuitive, to say the least. The suggestion I want to make is that charity, far from being a good thing, is wrong; that charity is in fact immoral. This may of course be thought a wild, and wildly implausible, claim. After all, charity is among the cardinal virtues; and charitable work is widely regarded as paradigmatic of morally laudable action. In brief, charity is generally regarded as just obviously a good thing but that charity is so regarded does not mean that that is what it is. While this is not the sort of extended and thorough treatment necessary to make the case that I think is there to be made, my hope is that it may act as a sufficient provocation, to be countered, explored in more detail or of course both.

So let me start by offering just one example by way of illustrating what I have in mind when I suggest that charity is immoral. It was recently reported in the UK that "Leading homelessness charities whose remit is to protect vulnerable rough sleepers have been passing information about some of them to the Home Office, leading to their removal from the UK" (Taylor, 2017). My contention is that the moral deformation this represents is not so much an aberration as something that arises from the function and form of contemporary charity. Recipients of charity are precisely on that account not fully people; they are less than the rest of us, and in particular less than those who offer them charity. The following quotations from the article speak for themselves:

Howard Sinclair, chief executive of St Mungo's [one of the charities involved], said: "The reality is that under current UK legislation, there are vulnerable people that are not eligible for support or housing and as a result are left destitute on the streets. When returning home is the only option for a vulnerable individual sleeping rough, we have to ask ourselves what would happen if we didn't get involved. The stark reality is that without any intervention people would simply deteriorate on our streets" (Taylor, 2017).

A spokesman for homelessness charity Change, grow, live (CGL) said: "Change, grow, live (CGL) do all we can to help rough sleepers to get help, regardless of their background or nationality. We work with a number of local authorities and statutory agencies around the country to reduce the risks faced by rough sleepers and find solutions to their sometimes complex needs. If employment or housing cannot be found for an EU national, we will offer supported econnection to that home country or somewhere they have relatives, and liaise with services there to ensure they have a place to go. When there is no other option and the person has refused reconnection, they are unable to work and cannot be housed, there is little alternative to them going back to their home country" (Taylor, 2017).

Insofar as the slightly better off refugees or asylum seekers who are not sleeping rough and who do not need to submit to St Mungo's or the CGL's complicity with inhuman UK 
government demands, they are more of a person than those who are on the streets. Moreover, the people in that position may be sacrificed in the name of charity; they may be sacrificed to allow St Mungo's and the CGL to offer charity to the 'natives'.

None of that, of course, is to say that everyone engaged in charitable work is thereby necessarily acting immorally. My target is structure, not individual intention. Nonetheless, if I am right that charity is morally problematic, then questions about complicity have to be asked about our engagement in it, in exactly the same way that questions about complicity have to be asked about our engagement in universities, school boards of governors, private health provision or indeed a whole host of public - and perhaps private - activities. For even if not all complicity is avoidable, it does not follow that such complicity is not morally wrong. ${ }^{1}$

\section{Charity}

Let me begin, then, by outlining what I take charity to be. Not that this is a matter of definition: as I have argued in another context (Brecher 2007, pp. 3-6), real things (objects, phenomena, movements, institutions) cannot be defined, but only described. That is why arguments about right and wrong, about what we should or should not do, cannot be settled by appealing to definition. If you think that that is a peculiar claim to make, consider a chair; and now try to define it. Can you do so? All that can be done is to try to offer as inclusive a description as possible. For the real world can always disrupt our descriptions: someone may invent a chair no one has yet thought of; new techniques of torture may be invented that evade capture under a previous characterization of the practice. In the same way, it is of course possible that in some world utterly different from our own, charity might not be what it is now. But that is another matter. What I am concerned with is charity as it is here, today, in our world.

Any description of charity must start with the recognition that voluntariness is central to it, both individually and structurally: unlike paying taxes, one is not compelled to donate to charities or to work for them; and unlike schools, the police or the armed forces, charities are voluntary associations in the 'civil society' sector. Another way of putting the point is that charity is supposed to be supererogatory; while it is not a moral obligation, it is nonetheless morally laudable. Compare diving into a rough sea to save the child apparently drowning in it: you don't have to try to rescue the child, but it is reckoned a good thing if you do.

Hence charity, for all that its roots lie in ancient traditions, is in its contemporary form a creature of the modern world, where individual and collective are carefully delineated. We are sufficiently autonomous individuals not to have to do what it is nonetheless good to do; and while collective obligations - often legally enforceable obligations - have their place, so does the supererogation that marks us out as individuals. That is why, for instance, the medieval institution of tithes occupied a space somewhere between charity and taxation (National Archives, no date). In many ways, the Christian Churches' system of tithes was very much like a tax, since (a) the Church was very often the local political master and (b) membership of the Church, like citizenship of a state today, was very much not a matter of choice. In other ways, however, the demand for tithes appealed (rightly or wrongly; realistically or otherwise; cynically or sincerely) to an understanding of the system of tithes as voluntary, as something freely chosen as part and parcel of one's membership of the Church. To that extent, such giving was regarded as both religiously and morally good. Why this comparison matters is that it illustrates that what it is for an action to be voluntary, or freely chosen, is not a straightforward given. It is something that requires to be understood somewhat differently in different social and political contexts and under different social and political structures. What is clear, however, is that it is only with the emergence of the view that 'individual' and 'social'

\footnotetext{
${ }^{1}$ For recent interdisciplinary discussion of the complex ramifications of complicity, see Afxentiou, A., Dunford , R. \& Neu, M. (2017).
} 
are fundamentally distinct that voluntariness can be understood in the way it is today, here in Europe; and that it can come to take on the importance that is accorded it. ${ }^{2}$ J. S. Mill's famous claim would have been unintelligible in, say, $13^{\text {th }}$ century Europe: The human faculties of perception, judgment, discriminative feeling, mental activity, and even moral preference, are exercised only in making a choice (Mill, 1989, p. 59). Of course, it is charity's voluntariness that makes it attractive: you are not compelled to give to charity; and charities, unlike state institutions, do not have to exist. Charity is supererogatory: it is at once more than you have to do and more than there has to be. Charity is not in any way obligatory; it is neither legally nor morally required. That is its point. While it may be morally admirable, it is not morally obligatory. You have to refrain from committing murder; but you do not have to give to charity. Killing someone for fun is clearly wrong; not giving to charity is not (obviously) morally impermissible.

All this gives rise to some interesting issues of detail. Consider, famously, Peter Singer. He thinks that everyone should give $10 \%$ of their income to charity; but even he does not think that this should be compulsory, rather than a matter of donation (though, in his case, that caveat may be a utilitarian one to do with consequential side effects rather than one concerning the logic of charity). ${ }^{3}$ For if charitable giving were morally mandatory, then of course, it would no longer be a charitable act, just because it would no longer be voluntary. Moral obligations, on the other hand, are not obligations that are simply voluntarily accepted; rather, they are required obligations - and according to some, rationally required. This raises of course a particularly controversial issue about the 'voluntariness' of morally mandated actions. As Kant famously insists, we should not be coerced by other people; but nonetheless, freedom consists in following the moral, that is to say the rational, law. But however one might wish to unpack the set of issues this raises, the central point remains and remains whether or not one sides with Kant about the nature of moral action that while charity is voluntary, saving a child apparently drowning in a shallow stream (at little or no cost to oneself, and other things being equal) is not. In short: if legally required, then charitable donation is a tax; if morally required, then charitable donation is not supererogatory. Again: compare a brave and morally admirable act, such as going into the proverbial burning house to rescue someone. If you do not rush into the house, that does not make you a moral pariah. Rescuing someone in those circumstances is supererogatory and that is what both giving to charity and working for charity are like. Neither resemble the sort of classic "child drowning in a shallow stream" case mentioned earlier: if you are walking beside a shallow stream and see a toddler in difficulty, you have to do something about it; simply to walk on would indeed make you a moral pariah, even if you were phobic about streams and could do no more than call for help.

It is this sort of case that raises the issue of borderlines. For example, is giving money to a famine relief organisation, or giving something warm to a homeless person on the street in the middle of a cold and wet winter, an act of charity? The obvious answer is that of course it is; that these are in fact paradigmatic instances of charity. But suppose that you are the only person around who can easily afford to give money, or the only person around who has spare warm clothes. And suppose that the needs in question are urgent. Then you might suppose that it is morally obligatory to give money or donate warm clothes.

It seems to me that the more morally required one takes such an act to be, the less it is to be understood as a charitable act. Compare again giving money to a beggar on the street. As I have suggested, one might entirely reasonably suppose that this is not something one is morally obliged to do, however admirable - possibly morally admirable - it might be to do so. But one might not think that: one might instead suppose that there is a moral obligation to

\footnotetext{
${ }^{2}$ Tithes may of course function rather differently in other religious traditions and histories.

${ }^{3}$ He sets out his position in Singer (2009).
} 
give every beggar some money to the point where one cannot afford to do so. In that case which is basically Singer's position - then it seems to me that one does not actually regard giving the beggar money as an act of charity at all, but rather that one supposes it to be a matter of moral obligation. Charity, that is to say, borders on being a moral demand without finally becoming such.

\section{Charity and dependency}

What I have just outlined is the source of what I take to be the moral problem about charity. Because charity is not morally required, it cannot avoid being a problem for the recipient of charity. Why? Because people receiving charity are thereby put into a position of dependency. They do not receive what they get as an entitlement. Note here that the phrases, 'receiving' charity, 'claiming' charity, or even 'getting' charity do not seem quite right. This should not be surprising. After all, charity - unlike welfare - is something people are supposed to be grateful for. Now, gratitude is of course fine - in its place. A friend sends me a book as a present: I am grateful. There is nothing mysterious here. Gratitude is an entirely appropriate response to a gift. But as a response to charitable provision?

Certainly it is the case that charitable giving is often understood as a sort of gift-giving. And this seems right: you give money or time to people who need it. But although this seems right, it is not. While charity might look like a gift, it is in fact something quite different. There are two respects in which this is so, and they are closely related. Both centre on people's needs. The first, and I think fundamental, point is that responding to a person's need differs from giving them a present; the second, which derives from the former, considers how responding to a person's need - since needs are necessities, and thus in a sense objective in a way that desires are not - morphs on that account into responding to a real need one supposes the recipient to have, as contrasted with what they themselves take their need to consist of. I shall come to this issue, that of paternalism, presently.

First, though, let us consider how giving someone something they need is different from giving them a present. The more that something is really needed by another person, the less someone's giving it to them can count as a gift. It is precisely because I did not need that book that it could be (and was) given to me as a gift. But charitable giving is not like that. Suppose I were starving and without the means to get hold of any food; and then suppose that someone gave me something to eat. Would that food be a gift, a present? It seems to me that it would not, just because it was something I really needed. Gifts, or presents, are not things I really need; in one sense, I do not need them at all, and being given something I do not need is a constitutive part of the pleasure of being given the book. On the other hand, however, if I am starving and need food, then that food is not a gift. Gifts are things that could be substituted by other presents; a bottle of wine could have taken the place of the book without any loss of its being a gift. Being given food, however, when starving is not like that; here, only food will do which is another way of drawing attention to its necessity, which is exactly what a genuine gift is not. Of course, the starving recipient of food might well feel grateful for it. But that is not the point. Rather, there is something wrong with their having been made to feel grateful for getting something they need; and that is one way of drawing attention to what is problematic about charity.

People do, however, tend nonetheless to think of charity in terms of gift-giving. If someone receives a 'charitable gift' then, surely, they ought to be grateful, just as though they should be grateful for a birthday present. No wonder the neo-liberal state couches its propaganda in precisely these terms: in the words of Her [UK] Majesty's Revenue and Customs, "If your donations are under the Gift Aid scheme, your chosen charity can also claim tax back (known as tax relief) from the government" (HMRC). The very idea of "Gift Aid' depends on conflating charity with gift-giving and so the UK tax authority's statement exactly mirrors 
government - and not just government - thinking. People in need should be grateful for what they are given. But charities deal with needs, and acts of charity address needs. So gratitude on the part of the recipients of charity is quite inappropriate, as many people who work for charities and/or who take part in charitable activities such as half-marathons in aid of suchand-such doubtless agree. But then they should have second thoughts about charity. The upshot of all this is that either charity supplies needs, in which case gratitude is not appropriate; or gratitude is appropriate, and perhaps appropriately felt, in which case what is at issue is not charity, but a gift.

So let me focus in light of that on the issue of people's needs being met through charity. The fundamental question is this: should needs be met by charity? I shall approach the question from two rather different angles, although angles which are in the real world very closely connected: what is charity like for its recipients; and what is charity like for its distributors?

\section{Recipients of charity}

This brings us to the second issue mentioned a few paragraphs ago. It may perhaps be brought out by considering institutional charity: the nineteenth century British workhouse, for example, or today's "overseas aid". The logic governing the workhouse was this: people who are starving on account of being too poor to buy food are poor on account of their being feckless; on account of their not being sufficiently responsible to meet their own needs. Simply to give them food would not change that state of affairs; indeed, it would exacerbate the problem. For that problem arises out of what their fundamental need is rather than the superficial one of hunger: and that fundamental need is to become a responsible person. Furthermore, it is by submitting to the discipline of work that one becomes a responsible, or real, person. The logic of "overseas aid", tied as it so often is to economic restructuring demands through the IMF or the World Bank, is exactly like this. Poor people's fundamental need is to learn to be responsible and efficient neoliberal economic actors - anything else is only a temporary sticking plaster and in fact inhibits just those changes that are required because it addresses only the symptoms of poverty, not its causes. That is why "restructuring" the economy - that is to say, imposing neoliberal discipline and values across the society concerned - is required.

Both examples have parallels with giving a young child pocket money but carefully circumscribing what they spend it on until they are sufficiently mature not to make feckless spending decisions and that is the model on which many of us come increasingly to respond to beggars on the street: here's some money, buy yourself something to eat - but don't spend it on alcohol. We might donate some tinned food to a food bank but can you imagine an alcohol or a tobacco bank? The point is that it is the donor who is the ultimate arbiter of another person's real needs and while that is entirely reasonable in the case of a young child, it is to treat adult recipients of charity as if they were young children and not the equals of "donors" as adults.

But even where that is not the case, where those who dispense charity do not take it upon themselves to make decisions concerning real needs on behalf of its recipients - and thus where the issue of unjustified paternalism does not arise - charity is nevertheless bad for its recipients. Let me indicate why. First, to have to rely on charity for one's basic needs - or perhaps even one's not so basic needs - to be met puts one in a position of dependency on the benevolence of others. And that at once reflects and creates a situation of radical inequality but it is precisely that inequality which is the root cause of the problem (assuming, of course, that the world's resources are as a matter of fact sufficient to meet everyone's needs, an 
assumption that I will not defend here but that I believe is an entirely reasonable one). ${ }^{4}$ It helps entrench apology, shame and dependency in terms of recognition as a person. Moreover, to go back to some of the earlier discussion, dependents have to show gratitude, however illogically. They have to perform their lives, not to live them. That is why you cannot give a present to a person who is dependent on charity - they are not properly a person. In short, recipients of charity, even of unconditional charity, cannot be the equals of donors, just because they are dependent on the latter. This is not an argument against our being dependent on one another - we are ${ }^{5}$ - but an argument against anyone being fundamentally dependent on others' benevolence, that is to say on the contingent convictions, preferences or whims of others (however sincere). It is why Kant insisted that an action performed out of benevolence could not be a moral action at all. And he was right.

\section{Dispensers of charity}

I shall end by gesturing in the direction of arguments about how engaging in charity might adversely affect those doing so, namely the dispensers of charity; that is to say, how it may adversely affect us. As in many other cases, the effects of actions on the actors concerned are all too often overlooked: compare for instance, capital punishment, imprisonment or interrogational torture (Brecher, 2007, pp. 68-72). Four issues, again inter-related, come immediately to mind; doubtless there are others. First, there is the issue of the extent to which being in a position to dispense charity (and 'dispense' is deliberately a loaded term here) may all too readily feed our egoism. In making us feel we are doing something good, it makes us feel virtuous; we are better people than those who do not give to charity. Second, it may too easily serve to salve our consciences by encouraging us to think we are doing all that can be done to make the world a better place - when that is not the case. Perhaps we should be doing something harder and something, moreover, that is much less clearly virtuous, namely fomenting political change. Of course, these two things need not be inimical: we could do both, and many do. ${ }^{6}$ But my worry remains the weight of charitable activity as compared to political activity; and particularly in structural terms. It is not so much individual psychology that is the problem, as the sheer political weight of charity, both individual and institutional. Finally, that weight itself tends, I think, to foster both a naïve optimism about the sort of place the world is and, closely associated with that, the self-delusion - both individual and social that is necessary to maintain such optimism. Think, for example, about the SOAS (University of London) report of 2014 on Fair Trade which showed how "wages on officially certified markets are below what is paid by comparable employers" (Vidal \& Provost, 2014). Yet "Fair Trade" continues to be celebrated as a progressive cause, naïve and self-delusory as that is.

\section{A provisional conclusion}

Some or all of these moral failings might well be forgivable - unavoidable, even. Certainly they characterize a good many features of our society other than charity. But that does not exonerate us. We are complicit in something that is wrong. It may be less seriously and/or obviously wrong than many other things but it is also more dangerous than many other things, just because it appears not to be wrong at all. In the end, the greater the moral demands a society makes of its individual members, the more problematic it is likely to be; to be a society in which individuals' moral sense has to make good the wider deficiencies of that society and such a moral sense is increasingly likely to require a degree of moral heroism. The obvious example is that of people under occupation. Today's neoliberal society, one that

\footnotetext{
${ }^{4}$ See for example Mohammad Habibur Rahman (2016).

${ }^{5}$ See Alasdair MacIntyre (2013) for a marvellous analysis of our dependencies.

${ }^{6}$ In the UK, War on Want is an unusual charity in being politically engaged and active, and in understanding the necessity of that to achieve its long-term goal of ending both poverty and unequal dependency together.
} 
outsources its political obligations to its members and/or to others, and is thus reliant on their moral convictions and willingness to act on them, is on the way to becoming such a polity. Think of how we treat refugees in today's Europe. ${ }^{7}$

Bob Brecher is a Professor of Moral Philosophy at the University of Brighton, UK. He is the Director of its Centre for Applied Philosophy, Politics and Ethics, and author of some sixty articles and book chapters, (co-)editor of five books and author of Anselm's Argument: the Logic of Divine Existence (Aldershot: Gower, 1984); Getting What You Want?: a Critique of Liberal Morality (London: Routledge, 1998); and Torture and The Ticking Bomb (Oxford \& New York: Wiley-Blackwell, 2007). He is a second-generation immigrant in the UK, his parents were born in the Czech Republic. His concerns about charity have their roots in a critique of the neoliberal revolution that has swept through Central Europe.

\section{Corresponding author:}

Bob Brecher, School of Humanities, University of Brighton, 10-11 Pavilion Parade, Brighton BN2 1RA, UK

Email: r.brecher@brighton.ac.uk

\section{References}

AFXENTIOU, A., DUNFORD, R. \& NEU, M. (eds.) (2017): Exploring Complicity. London: Rowman \& Littlefield International.

BRECHER, B. (2007): Torture and the Ticking Bomb. Oxford: Wiley-Blackwell.

GUARDIAN (2017): The valley rebels (video). [online]. [Retrieved 1 May, 2017]. Available at:https://www.theguardian.com/world/ng-interactive/2017/apr/28/the-valley-rebels-the-

french-farmer-helping-refugees-cross-europe-video

HMRC (no date): Gift Aid [online]. [Retrieved March 14, 2017] Available at: http://www.hmrc.gov.uk/individuals/giving/basics.htm

MACINTYRE, A. (2013): Dependent Rational Animals. London: Bloomsbury.

MILL, J. S. (1989): On Liberty, ed. by S. Collini. Cambridge: Cambridge University Press.

NATIONAL ARCHIVES (no date): Tithes [online]. [Retrieved April 1, 2017]. Available at http://www.nationalarchives.gov.uk/help-with-your-research/research-guides/tithes/

RAHMAN, M. H. (2016): Exploring sustainability to feed the world in 2050. In: Journal of Food Microbiology, 1(1), pp. 7-16 [online]. [Retrieved May 1, 2017]. Available at: http://lawarencepress.com/ojs/index.php/JFM/article/view/273/540

SINGER, P (2009): The Life You Can Save. New York: Random House.

TAYLOR, D: Charities referring rough sleepers to immigration enforcement teams [online]. [Retrieved 10 March, 2017]. Available at:

www.theguardian.com/society/2017/mar/07/charities-giving-home-office-details-of-rough-

sleepers says-report

VIDAL, J. \& PROVOST, C. (2014): Fairtrade accused of failing to deliver benefits to African farmworkers. Observer, May 24, 2014 [online]. [Retrieved 1 May 2017]. Available at: https://www.theguardian.com/global-development/2014/may/24/fairtrade-accused-of-failingafricas-poor

\footnotetext{
${ }^{7}$ For one recent example of moral bravery in this context see the Guardian video, The valley rebels (2017).
} 